\title{
Controversies and Intrigues Behind the Introduction of Development Areas by Some State Governments in Nigeria: Matters Arising
}

\author{
Badejo Atinuke Bolaji (Ph.D) \\ Department of Local Government Studies, Obafemi Awolowo University, Ile-Ife, Osun State, Nigeria \\ Adekeye Joseph Adeshola (Ph.D) \\ Department of Public Administration, University of Abuja, Fct, Abuja, Nigeria. \\ Adeoye Julius Olaniyi (PhD) \\ Department of Political Science And Public Administration, Adeleke University, Ede, Osun State, Nigeria
}

\begin{abstract}
It is known fact that various school of thought exists on whether the State government has the constitutional right to create development areas or not. Some are of the view that the creation of development areas is a way of bringing government closer to the people at the grassroots level while others considered such move as a way of siphoning public fund into private pockets Thus, the aim of this study is to examine the necessity or otherwise of introducing development areas within the existing constitutionally recognized local government councils at the State levels in Nigeria. In efforts to achieving the objective of this study, a qualitative technique of data collection and analysis of existing documents, reports, bulletin, records and official publications was adopted. At the end of the study, it was discovered that most States that created development areas are not faring better in terms of revenue generation, infrastructure development and provision of social amenities to citizens despites the supposedly benefits drivable from such decisions. In most cases, such initiative only succeeded in increasing the cost of governance through astronomical rise in the recurrent expenditures. In other words, statutory allocations meant for existing local councils are now being shared to development areas without any form of returns thereafter. Therefore, this study recommended for the scraping of development areas in order to channel available resources at the local councils to the implementation of viable projects that have direct bearing on improved standard of living for rural dwellers.
\end{abstract}

DOI: $10.7176 / \mathrm{PPAR} / 9-5-06$

Publication date:May $31^{\text {st }} 2019$

\section{Introduction}

One of the major justifications for the creation of development areas in modern polity is that it promotes political participation by local communities in governmental activities as well as serving as machinery for harnessing local efforts for developmental purposes. Apart from facilitating participation in governmental activities at the local level, development areas also serves as a bridge and channel of interactions between local populations and higher levels of governments. The idea of creating development area alongside the already exiting local government in Nigeria was first muted by Governor Raji Fashola of Lagos during the administration of President Olusegun Obasanjo (1999-2007). During the period, Governor Raji Fashola created additional 37 development areas alongside the already existing 20 local governments. This singular act generated a lot of controversies between the Federal government and Lagos to the extent that the matter was later resolved by the Supreme Court. Subsequently, Niger, Ebonyi, Katsina, Yobe, Nassarawa and Adamawa States created development areas as veritable tools for bringing government closer to the people at the grassroots level.

Maddick (2003) suggested that development engineering in developing countries requires decentralized structures and attitudes of cooperation between those at the centre and those at the rural settings. He further suggested that bridging the centre and the localities would require the establishment of administrative and governmental institutions at the local level, in which the villages and towns can be brought together to realize what they lack in the way of better mode of living within the country. What the foregoing comments seems to suggest is that development areas can play an important role in the process of harnessing human and material resources for local and national development.

The lofty ideals for the creation of development areas in recent time have been appraised by many for its developmental strides, though they are some dissenting voices who have criticized its creation especially as they query that money given to them as monthly allocation, subvention or whatever names it goes with is not commensurate with the level of infrastructural facilities it claims to have provided for the rural populace at a monthly or yearly basis (Ibeogu, 2015). These critics maintained that the proliferation of development centres have not made any impact in the life of the rural areas and so should be scrapped, especially when it is not 
recognized by the government of the federation, but established by an act of the State legislative arm.

However, much as they are critics or proponents whose position is that the development centres should be scrapped on the grounds of non performance, corruption and duplication of roles, duties and responsibilities, it suffices to say that its commitment to the transformation of rural life should be appreciated as it has impacted positively on the people's lives in the area of education, healthcare service and aggressive rural development and employment opportunities. The orchestrated positive impacts of the development areas at the state level cannot be completed without an insight on its attendant challenges. Development areas are the creation of the State government. Therefore, the policies pursued by these rural government are only and mostly directed by the State government, Ministry of Local Government and Chieftaincy matters, Local Government Service Commission and House of Assembly (Ibeogu,2015).

Other militating factors militating against effective administration of development areas bother on the fact that indigenous workforce often sees other workforces that are not indigenous to their area as a threat to their career progression. This attitude most often affects the smooth running of the centres by the coordinators (administrators). There have been several instances whereby a particular treasurer, Head of Personnel (HPM), Auditor, and Cashier who is not from the development area neither relate well with the subordinate staff or coordinator (Administrator). In such a situation, the coordinator of the development centre moves to the Local Government Service Commission and influence the posting of such principal officer. Similarly, some principal officers of the development areas (Coordinator, HPM, Treasurer, Auditor, and cashier) are not adequately trained to handle human diversities in an organization in a way that will bring unity in diversity in such organization. This is most likely in situations whereby the chief executive or heads of the organization are not proficient in the art of administration. In view of the above, the paper aims to examine the contending issues and implication of creating development areas from existing local councils by State government in flagrant disregard to constitutional provisions.

\section{Conceptual Clarification}

In efforts to fully grasp the contending issues inherent in a paper of this nature, it is instructive to conceptualize some terms considered critical to the study based on the opinions of notable authorities in the field of local government and development administration. Such terms include:

\section{a)Development Area}

Development Area like local government has been regarded as the third tier of government, which aid the development of grass roots where states and central government (federal government) cannot fully cover. Development area is equally refers to as a unit smaller than the local government in rural setting. It was therefore designated to ensure even development of the nation from the below while filling the gap the federal government is unable to fill (Okpata, 2004). Similarly, development areas were created to bring economic, social, political and government closer to the people of the grass root.

\section{b) Local Government}

There are various definitions of local government as provided by scholars, practitioner or administrators. A local government according to Ademolekun (1983) is a government at the grassroots level of administration meant for meeting peculiar grassroots need of the people. Appadorai (1975) defined it as a government of the popular elected bodies charged with administrative and executive duties in matters concerning the inhabitants of a particular district or place.

Lawal (2000) also defined local government as that tier of government closest to the people, which is vested with certain powers to exercise control over the affairs of the people in its domain. Olisa et al (1990) defined local government as a unit of government below the central, regional or state government established by law to exercise political authority through a representative council within a defined area. The United Nations Office for Public Administration (1976) defines local government as a political sub-division of a nation or (in a federal system) state, which is constituted by law and has substantial control of local affairs, including the powers to impose taxes or to exert labour for prescribed purpose. The governing body of such an entity is elected or otherwise locally selected. The guidelines for a reform of local government in Nigeria define local government as:

Government at the local level exercised through representative council established by law to exercise specific powers within defined areas. These powers should give the council substantial control over local affairs, as well as the staff and institutional and financial powers to initiate and direct the provision of services and to determine and implement projects, so as to complement the activities of State and federal government in their areas, and to ensure, active participation of the people and their traditional institutions, that local initiatives and response to local needs are maximized(1976, local government reform).

A glance at the above definition shows that local government is synonymous to the concept of devolution. Devolution presupposes the exercise of political authority by primarily elected institutions within a legally 
specified areas, usually, "local units (which) are autonomous, independent and clearly perceived as separate levels of government over which central authorities exercise little or no direct control. It is a total transfer of authority from the central government to the local unit.

Local administration on the other hand refers to a mere delegation of authority from the higher level of government to the local unit. In practice, local administration portends limited or restricted form of decentralization in which the central government assigns functional responsibilities to its appointed agencies (which could be a sole administrator or caretaker committee) at the local level to provide certain services. Therefore, local administration is synonymous with de-concentration of authority. According to Rhodes (1992: 317 ), de-concentration is referred to as field administration where appointees of higher levels of government are delegated to the grassroots to administer them on behalf of the higher authorities. In the words of Oyadiran (1998:69), local administration is the administration of local communities essentially by means of local agents which may be state, region or national government.

Local Government autonomy on the other hand is the freedom of Local Governments to exercise authority within the confines of the law or constitution. This is to enable them to discharge legally or constitutionally assigned responsibilities satisfactorily, but without undue interference or restraint from within or higher authority.

According to Adeyemo (2005) "Local Government autonomy is perceived as local self-government or grassroots democracy". This grassroots democracy is primarily aimed at giving the vast majority of the people the fullest opportunity to participate in determining their own destiny. But it is obvious that we cannot have complete autonomy or complete local self-government within sovereign states. If local governments were completely autonomous they would be sovereign states. Nwabueze (1983) as cited in Adeyemo, 2005) defines the autonomy under a federal system to mean that "each government enjoys a separate existence and independence from the control of the other governments" It is an autonomy which requires not just the legal and physical existence of an apparatus of government like a legislative assembly, Governor, Court etc. but that each government must exist not as an appendage of another government but as autonomous entity in the sense of being able to exercise its own will in the conduct of its affairs free from direction of another government.

In the opinion of Nwabueze (1983), autonomy would only be meaningful in a situation whereby each level of government is not constitutionally bound to accept dictation or directive from another. In the view of the defunct Centre for Democratic Studies (cited in Adeyemo, 2005) local government autonomy refers to "The relative discretion which Local Governments enjoy in regulating their own affairs". The extent to which Local Government are free from the control of the State and Federal Governments encroachment in the management of local affairs. In the same vein, Davey (1991) contends that:

Local autonomy is primary concerned with the question of responsibilities, resources and discretion conferred on the local authorities. As such discretion and responsibility are at the core of local government". It presumes that local government must possess the power to take decisions independent of external control within the limits laid down by the law. It must garner efficient resources particularly of finance to meet their responsibilities, put differently; local autonomy is the freedom of independence in clearly defined issue, areas, as well as separate legal identity from other levels of government.

It is important to note that considering the country's federalism and constitution there can never be an absolute autonomy because of the interdependence of the three levels of government and this bring into focus the intergovernmental relations of local government autonomy. The federal, state and local governments rule over the same population. If they are to achieve the purpose of their creation and not to waste the meagre resources at their disposal, there must be a definition of the boundaries or arena of operation of each of them. In essence, when one talks of local government autonomy in Nigerian's polity, it refers to the relative independence of local government control by both the state and federal governments. Therefore, it is the nature and structure of transactions or interactions between the three levels of government that reveals the degree of local government autonomy Adeyemo (2005).

The country's constitution clearly spelt out its position on Local Government autonomy, for instance the exit of the military and the enthronement of the democratic government in 1999 brought to the fore, again, some contradictions of local government autonomy. The provisions regarding local government administration in the 1999 Constitution created a lot of confusion. The 1999 constitution by its provisions in section 7 and 8 recognise the local government as a third tier of government and also guarantee it, but gives the state the autonomy to lord over the local government. Section 7 reads jointly with Section 8 provides that there shall be:

The system of local government by democratically elected councils (which) is by this Constitution guaranteed and accordingly, the government of every State shall, subject to section 8 of this Constitution.... ensure their existence under a law which provides for the establishment; structure, composition, finance and functions of such councils.

The implication of these provisions according to Asaju (2010) is that local government cannot exercise the functions assigned to it in section 1 schedule 4 of the Constitution until the State House of Assembly had passed 
a law. The same Fourth Schedule of the Constitution also provides for "the functions of the Local government Council to also include participation of such Council in government of a state as in respect of the following matters, education, agricultural materials resources, healthcare and any other function assigned to it by the State House of Assembly Asaju (2010).

\section{Rationale for the establishment of local government and Development Areas}

A lot of reasons have been advanced for the evolution and creation of local governments in Nigeria. These range from political, social and economic reasons. Over the years, there has not been a general consensus as to the precise role local government should play, this singular factor makes the problem regarding the objectives of local governments most important. The following are seen as the purpose for the creation of local governments in Nigeria.

(1) To Bring Governance Closer to the People: Local government functions to bring democracy to the local citizens as well as to educate and socialize them politically; participation of the citizens in governance is one of the underlying percepts of democracy. Due to the vast nature of the country (Nigeria), the presence of governments whether at the federal or state levels was not well felt by the people, and this led to neglect and distrust of government by the people. In a bid to bring the activities of government closer to the people, local governments were created to serve as conduits through which government's policies are communicated to the people (Aigbakoba and Ogbonna 2004).

(2) For Administrative Convenience: Local government serves as a channel through which policies and programmes from the state and federal government are communicated and implemented. This is because there are many functions that will be cumbersome for the state and federal governments to perform because of the distance separating them and the people e.g:

(a) Collection of rates, radio and television licenses;

(b) Registration of births, deaths and marriages registry etc.

The local government was also created to serve as the representative of both the federal and state governments amongst the local people. It is a channel through which policies are communicated and implemented (Aigbakoba and Ogbonna 2004).

(3) To Ensure That Resources are effectively Mobilized: This is to arouse in the citizens the zeal or willingness to contribute financially, materially and morally to the management of local affairs. Local governments are created to bring about meaningful development in the rural areas through the effective mobilization of resources. Local government use the funds made available to it by both federal and state governments and their internally generated revenue to improve on the lives of the people within their areas of operations (Aghayere 1997).

\section{(4) To Preserve Heritage and Common}

Interest of the People: In Nigeria today, there are over 364 ethnic groups with diverse cultures and tongues. These ethnic groups are further divided into communities. These communities form the constituents/areas of local governments in Nigeria. By carving out local governments from amongst people of the same community, government is preserving such long traditional associations and using same to foster the interest of the people concerned. The creation of local government is intended to bring people of common heritage or ancestry together as a political unit to further their interests and increase their participation in government business. It should be noted that, the broad objective of establishing local government is placed on the service delivery function. When roads are bad, when there are no markets stalls, no health centres, when there is no water, no drugs in the local dispensaries and when refuse is littered all around the place etc, the ordinary citizen blames it on the local government. It follows, therefore, that local government administration is established to affect citizens through the service delivery function (Aghayere 1997).

\section{Theoretical bases for local government/ Development Area creation in Nigeria}

There are different schools of thought that are relevant to this study. These are the Democratic- Participatory school, Systems theory, Integrated theory and Functional theory.

(i) Democratic-Participatory School: The school advocates that local government exists essentially for bringing about democracy to afford opportunities for political participation to the citizens, as well as educate and socialize them politically (Adamolekun, Olowu and Laleye,1988). This means that local government is to foster representative and participatory democracy at the lower level, Mills (1964) work on Utilitarianism, liberty and representative government has greatly influenced this school of thought. Mills asserts that local government is a prime element of democracy and demonstrates the intrinsic values of democracy irrespective of the service it produces in it that local government offers' the, closest thing to widespread consultation and participation. Studies carried out by Keith Lucas revealed that a large number of British members of parliament who had served on local government demonstrated the importance of local government as a recruiting ground for the British parliament. An analysis of the 1964 general election by Davis Butler revealed that 53\% of the labour 
members of parliament and $45 \%$ of the defeated labour parliament candidates had been one time Local Government Councilor (Noun. 2010). Mackenzie (1954) supported this when he produced a data proving that more than half of the deputies and about the same proportion of senators in Italy had had political education in the local government. A very important part of this democratic role is the opportunity it creates for political activity and social interaction. Such a forum helps to inculcate the ideal of democracy like election or selection of local committees and boards, public debates, pressure and interest group activities (Afegbua, 2011)

(c) Systems Theory: This is a multi-disciplinary approach to the analysis of political events. It presumes the existence of other components which make it a whole, and which are also in constant interaction and interdependence: A system's theory is a conceptual framework and methodology for understanding the operation of a system where there are two or several actors that are essentially components of the whole. Systems theory is therefore defined as a series of statements about the relationship among independent variables in which changes in one variable is accompanied or followed by changes in other variables. In a functional democracy, the application of the system theory cannot be over emphasized. This is because it addresses the issues of interdependence, dependence and interactions of variables. Notable scholars in systems theory include Anatol Rapoport, Talcott Parson and Dario Easton.

(c) Integration Theory: This is concerned with making a whole out of the components that make up a nation state. Integration theory is a process that links a given nation state to others. Integration helps to catalyse the process of: interaction between and among states in nation state. Indeed, political integration has been 'linked to functionalism. It holds the view that the society as system is made up of inter-related parts .All do interact on the basis of a common value system or consensus about basic values and common goals (Ndolo, 2005). Practically, every social custom and institution is seen as having a function in ensuring that society works efficiently. The maintenance of political integration are maintenance of peace, attaining greater multi-purpose capabilities, accomplishing specific task and gaining a new self-image and role identity.

(d) Functional Approach: This is an approach to the study of democratic governance propounded by Gabriel Almond. According to Anifowose and Enemuo (1999), taking Easton's analysis as a starting point, Almond looks for the functions which he included among the input acid output functions of 'all political systems. On input, Almond stated the functions of rule making rule, rule application and rule adjudication. Since every system ensures it maintenance and sustainability, it becomes imperative that, there should be system maintenance and adaptive, functions through political socialization and recruitment of people to ensure the workability of democracy and good governance. A functional democracy would necessarily ensure good governance and nation building. Critics of Almond have contended that the system cannot distinguish between the deliberate aims of participants and what takes place. Functional school would be adopted because it has been recognized as a major existing tool for genuine comparative analysis of political systems.

\section{Argument for and against the creation of development areas in Nigeria}

The 1979 Constitution delineated a three tiered federal structure in which each tier, particularly the Federal and State Governments, enjoy a considerable measure of independence jurisdictionally, financially, and functionally even if several forces appear to tilt the balance of power in favour of the centre, and rarely in favour of State Governments and Local Government Councils, and even if constitutional provisions see LGCs as subordinates in

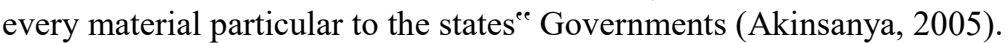

As rightly observed by Akinsanya, state Governors not only exercised their powers under Section 7(1) of the 1979 Constitution to dissolve "elected" LGCs and replace them with sole Administrators or caretaker committees but also created new LGAs. Although the constitution enjoined states to pay 10 percent of the statutory revenues to LGCs, very few states honoured the provision. In fact, some states forced some LGCs to make contributions for the provision of some services like primary education. Additionally, statutory allocations from the "Federation Account" to LGCs, paid into states-joint Local Government Account by some state Governments. By and large, LGCs were emasculated through acts of omission or commission by some state Governments.

It is a fact that the 1999 Constitution of the Federal Republic of Nigeria ushered in a democratically elected regime on May, 29th 1999, and the 1979 Constitution, provides for three tiers of government: Federal, State and Local, and that each level of government is independent in the sense that one level is not subordinate to the other in legal authority. Specifically, it has been argued by Akinsanya that:

Local Government Council are autonomous entities, and therefore, should be treated as such.

However, the much touted autonomy of LGCs, if that was the intention or intendment of the "authors" of the "1976 Local Government Reforms", flies in the face of facts and constitutional provisions (2005:28).

That the ,authorse of the 1999 Constitution, like the 1979 Constitution, paid little or scant attention to Local government as the third tier of government is no longer in doubt. Indeed, from all indications, the local government is the least important of all the three tiers of government just like the "Third World is the least 
important in the comity of nations". A careful examination of the distribution of powers among the three-tiers of government under the 1999 Constitution and the practice of Inter-Governmental Relations (IGRs) in the ongoing democratic dispensation, clearly shows the total subordination of Local Government Council (LGCs) to the other two tiers of government (centre and federating states). The question we now ask is, what then is the Locus of a local government council as the third-tier of government in Nigeria? Section 7(1) of the 1999 Constitution provides unambiguously that:

The system of local government by democratically elected local government council is under this constitution guaranteed. Accordingly, the Government of every state shall ensure their existence under a law which provides for the establishment, structure, composition, finance and functions of such councils.

The contradictions in the provision of the 1999 constitution on local government did not help matters, and set the stage for the later struggle between the federal and state governments over control of the localities. In 2003, at the height of the struggle and controversy over levels of government, the federal government set-up a technical committee on the Review of the structure of local government councils to review and consider the desirability or otherwise of retaining local government as the third-tier of government

One of the major recommendations of the committee was the reintroduction of the parliamentary system at the local government level in view of what it considered the expensive and wasteful nature of the presidential system at that level. This, and the landmark Supreme Court ruling of 2001 which affirmed state responsibilities for local government, were perhaps the queue state governments were waiting for to perform their own experiments. Taking their authority from section 7(1) of the 1999 constitution that guarantees democratically elected local councils and empowers state governments to enact laws for the "establishment, structure, composition, finance and functions" of the councils, and if section 128 of the constitution also empowers a State's House of Assembly "to direct or cause to be directed an inquiry or investigate into - (a) any matter or thing with respect to which it has power to make laws; and (b) the conduct of the affairs of any person, authority ; charged with the duty of or responsibility for (i) executing or administering laws enacted by the House of Assembly, and (ii) disbursing or administering moneys appropriated or to be appropriated by such House", then the Dillon "s Rule enunciated by the Iowa state chief judge is apt in describing state-Local Relations in Nigeria (Deil, 1978). In the absence of any legislative enactment, and/or constitutional provision to the country, states can determine not only the tenure of elected Local Government officials elected prior to the coming into force of the 1999 constitution.

For a number of reasons, the president (Obasanjo) and the National Assembly decided that the 2002 Local Government Elections must be postponed, and this by extending the tenure of office of elected local government officials by one year through the Electoral Act of 2001 by invoking item 11 of the Concurrent Legislative list providing that:

The National Assembly may make laws for the Federation with respect to the registration of voters and the procedure regulating elections to a local government councils.

The word "procedure" was interpreted, and albeit wrongly to include timing of the election and tenure of those elected in order to justify the extension of the tenure of elected local government officials notwithstanding the provisions of sections 312(2) of the 1999 Constitution which states that:

Any person who before the coming into force of this constitution was elected to any elective office mentioned in this constitution in accordance with the provisions of any other law in force immediately before the coming into force of this constitution shall be deemed to have been duly elected to that office under this constitution (Jinadu, 2005:30).

As Akinsanya rightly noted, all efforts made to convince members of the relevant committees of the National Assembly, that they don't have such powers, and would be ultra vires fell on deaf ears. When the Supreme Court ultimately invalidated the provisions and ruled that the National Electoral Commission, a federal executive body, which had been conducting bye-elections to fill vacancies in some states Assemblies refused, failed or neglected to make available to the states ${ }^{\text {ee }}$ Independent National Electoral Commissions the voters Register to conduct Local government elections due in March 2002, and at the end of the day, President Obasanjo and statese ${ }^{\text {ee }}$ Governors agreed to an unconstitutional procedure of appointing for two years caretaker, interim or transition Local Government Councils contrary to the provisions of Section 7 (1) of the constitution guaranteeing "the system of Local government by democratically elected local government council."

It is obvious that that 1999 Constitution is more elaborate than the 1979 Constitution in its provisions on Local government with specific reference to number of local governments in Nigeria and the method of creating new ones. Obviously an off-shoot of Babangidaes 1989 , constitution which significantly curtailed state rights in Local government matters, the 1999 Constitution made it very difficult for states to exercise absolute jurisdiction changing the boundaries of local government, by not only stipulating the number of local government (774) in existence in Nigeria and mentioning them in part I of the First Schedule but also gave the National Assembly the power of assent in the events of creation of more local governments by any state. As Obianyo (2005) rightly 
observed that:

$$
\text { It would appear that the military regimes after creating many local governments put a seal }
$$

to more creation by any state by including the names of local government in the constitution

to make more creation difficult as it being experienced in Nigeria today.

Obviously, only states can create new Local Government Areas pursuant to section 8 (3) of the constitution, and as if the constitution does not envisage, contemplate, nor anticipate the creation of new states and LGAs pursuant to Section 8 (1) and Section (3) of the constitution. Specifically, Section 7 (1) of the constitution empowers a state Government to enact a law providing for the establishment, structure, composition, financial and functions of such councils. It should however be stated that the case of the impasse between the Lagos state governments and the federal government in 2004 which was widely celebrated one. The different interpretation that was given by the two parties to Section 8 (5) and 8(6) as to whether Lagos state has satisfied or fulfilled the provisions of the constitution in relation to the afore-stated sections led to a constitutional crisis. The crisis is significant in view of former President Obasanjo's refusal to release the federal allocation to local governments in Lagos state on the grounds of violation of the 1999 constitution of the Federal Republic of Nigeria. On the directives of President Olusegun Obasanjo to the Minister of Finance in April 2004, to states that created additional LGAs;

No allocation from the federation account should henceforth be released to the Local government councils of above mentioned states (and any other that may fall into that category until they revert back to their local government areas specified in part one of the first schedule of the constitution (Obasanjo 2005).

The affected states were Lagos, Ebonyi Katsina, Niger and Nasarawa. The affected sections of the 1999 Constitution with reference to federal revenue to Local government and state are as stated in section 162(3) viz: An amount standing to the credit of the Federal Account shall be distributed among the Federal and state governments and local government councils in each state on such term and in such a manner as may be prescribed by the National Assembly (Sec 162(5). The amount standing to the credit of local government councils in the federation account shall also be allocated to the states for the benefit of their Local Government Councils on such terms and in such manner as may be prescribed by the National Assembly (Sec 162(6)

Each states shall maintain a special account to called "state Joint Local government account" into which shall be paid all allocations to the Local government councils of the state from the federation account and from the government of the state. Sec 162(7), each state shall pay to Local government councils in its area of jurisdiction such proportion of its total revenue on such terms and in such manner as may be prescribed by the National Assembly. Sec 162(8)

The amount standing to the credit of Local government councils of a state shall be distributed among the local government councils of that state in such terms and in such manner as may be prescribed by the House of Assembly of the state. The Lagos state took the federal government to court on this matter, and prayed the court to determine whether or not there is power vested in the president of the Federal Republic of Nigeria (by executive administrative action) to "suspend or withhold for any period whatever the statutory allocation due and payable to the Lagos state government, pursuant to the provision of Section 162(5) of the constitution of the Federal Republic of Nigeria.

On December 10, 2004, in a lead judgment by the chief Justice of Nigeria Muhammadu Lawal Uwais, the Supreme Court, in Attorney-General of Lagos State V Attorney-General of the Federation, ruled:

(a) The federal government has no power, either by executive or administrative action, to suspend or withhold for any period what so ever, the statutory allocations due and payable to Lagos state government pursuant of the provision of Section 162 (8) of the 1999 constitution.

(b) Such withholding of due allocations is unlawful and contrary to the provisions of the 1999 Constitution. The chief Justice Uwais maintained further that the creation of new Local government areas or councils is supported by the provision of the constitution.

Justice Samson Uwaifo"s comment was more explicit, and caustic: "It does not appear to me that there is any power contained by the president to withhold any allocation on the basis of a conceived breach of the constitution."

Justice Niki Tobi on his part asked a rhetorical question: "does the president have right to stop the release of funds to the councils?" I think not". He notes that, "section 162(9) of the Constitution or any other section for that matter does not provide for the stoppage of allocation from the federation account to the local government councils of Lagos or any other state". Justice Idris Lagbo Kutigi also asserts "Nowhere in the constitution is the president expressly or impliedly authorized to suspend or withhold the statutory allocations payable to Lagos state pursuant to section 162(5) of the constitution, on the ground of complaints made against Lagos state by the Federal government in this section or any ground at all. If the president has any grievance against any tier of government, he shall go to court. He cannot kill them by withholding their allocation.

In essence, the Lagos State Government was right in creating new LGAs, while president Obasanjo has no 
power to suspend/withhold statutory grants due to Lagos State Government for benefit of its Local Government Council. True, is it that the Supreme Court ruled that the statutory grants withheld are meant for the benefit of 20 LGAs but not 57 LGAs since they cannot come into operation until the National Assembly passes an Act amending Section 3(6) of the constitution and part 1 of the first schedule to the constitution? The Federal Government refused, failed or neglected to release these grants to the Lagos State Government on the spurious grounds that the LASG is likely to use the grants for the benefit of 57 LGAs, and not 20 LGAs recognized by the constitution, thus, raising serious questions whether the president is above the law and/or whether the president is not in serious violation or breach of the provisions of the constitution.

It seems the president has an ass to grind with Lagos state, as it did not withhold the statutory allocation of other states like Yobe state which did exactly what Lagos did. Yobe created additional 23 Local governments in addition to its earlier 17 bringing the total to 40 Local governments but was never penalized by the Federation government. The other states e.g, Ebonyi, Katsina, Nasarawa and Niger turned their respective new Local government areas (LGAs) into what they called „Development Areas (Obianyo, 2005).

Before the adoption of federalism as a system of government in Nigeria, colonial system of local government administrator was the order of the day. Borrowing from the system in the colonizing country, the British colonial authority leaned heavily on unitary system of government as a model for running this newly created nation state. The formation of government in Nigeria thus began with development of local government; the second republic witnessed the test of Nigeria's federalism regarding territorial relationship between the states and local governments.

Constitutionally, the states are supposed to create local governments and the due process for doing so are equally laid down by the constitution, since 1976 local administration has successfully created any local governments were abolished when the military took over power in 1983 (Ogunsola, 2009). According to Maduagwu (2003), the return to civil rule in 1999 threw up a serious debate as to which level of government has the constitutional power to create local government. Lagos State created more local governments, but Federal Government refused to recognize them, insisting that creation of local government requires constitutional amendment by the National Assembly. Due to politics and other reasons many state governments embarked on the creation of local governments without recognition by the National assembly which lead to mockery of the state by federal government. Creation of local government, according to the chairman of the then Senate

Committee on local government, Senator Tunde Ogbeha emphasized that it require constitutional procedures which Lagos State government have not followed. The business of creating local governments in Ogbeha's tenure, is between the community seeking such council, the State House of Assembly and the National Assembly (Maduagwu, 2003).According to Dasuki Report, Military Governors, "in consultation with the local government concerned could create Area Office(s) after clearance with the General Staff Headquarters" (Federal Military decree 1985).

Under the fourth republic, though the states could create local government but such creation becomes real only after it was approved by the National Assembly. Theoretically, therefore, state and local governments could create local government; Area Council and Wards respectively, practically, they must seek clearance from the Federal Ministry of Intergovernmental Affairs. Lagos State whose monthly federal allocations to the local government has been withheld for more than six years, salaries of works of such local government were unpaid while developmental projects were also stalled, Lagos State government restored to however, the conversion of the newly created local governments to Area Office with their headquarter located in the said Area Offices as local government. On June, 2007, the newly democratically elected president, in person of Umar Yar'Adua paid all the six years monthly federal allowance to the Governor Babatunde Fasola of Lagos State; this follows the rule of law in his administration (Ogunsola, 2009).

Many state governments especially during civilian administration 1999-to date embarked on creation of local governments but only few could see the light of the day due to many problems that bedeviled local governments, some perished after few years of their existence, while others suffered from problems ranging from politics to lack of continuity, dearth of funds and inability of the national assembly to recognize it as a true tier of government due to politics of confrontation, mockery of state where the dominant party is not in control of such states. A clear picture of this was Lagos state; the state went ahead and created many area development council but were not recognized by the federal government due to party differences (Danjuma, 2012). However, in recognition of the Lagos mega city challenges and in order to bring governance, development and participatory democracy nearer to the local people increased in June, 2002 with the creation of additional 37 local governments bringing the number of the local governments in the state to 57 (Agboola, 2009). 
Tabular Analysis of the Creation of Development Areas in Nigeria

\begin{tabular}{|l|l|l|l|}
\hline State & Old Local Government & New Local Government & Total \\
\hline Lagos & 20 & 37 & 57 \\
\hline Kebbi & 20 & 20 & 40 \\
\hline Ebonyi & 13 & 23 & 34 \\
\hline Katsina & 34 & 30 & 64 \\
\hline Nasarawa & 13 & 16 & 29 \\
\hline Niger & 25 & 17 & 42 \\
\hline Yobe & 17 & 23 & 40 \\
\hline
\end{tabular}

Source: Danjuma and Muhammad, 2013

The table above, it shows that many states created local government that are more than the old local governments for instance Lagos created 37 new area development council otherwise known as new local governments, Kebbi added another 20 area development council, Ebonyi state also created 23, Katsina state 30, Nassarawa state 16, Niger 17 and Yobe state created 23 without adequate funding especially during this period of global financial meltdown, the possibility of such local governments to see the light of the day is very meager.

Lagos State was created on May 27, 1967 by state (creation and Transition) decree No 14 of 1967, which restricted the Federation into 12 states. Prior to this, Lagos Municipality was administered by the Federal Government in respect of Federal Ministry of Lagos Affairs as authority, while the Lagos City Council was governed the city of Lagos. Equally, these council areas (colony province) of Ikeja, Ikorodu, Epe, Badagry and Mainland were administered by the Western Region. The state took off as an administrative entity on April 11, 1968 with authority of serving the dual role of being the state and federal capital. However, with the creation of the Federal Capital Territory of Abuja in October 1st, 1979, Lagos Island ceased to be the capital of the state which was moved to Ikeja, the formal relocation of the seat of the federal government to Abuja in December, 1991, Lagos ceased to be Nigeria's political capital. Nevertheless, Lagos remains the nation's economic and commercial capital to extent political records. "Lagos is to the people of Nigeria, what the body is to an individual" (Agboola, 2009). The divisions are further divided into 20 local government areas in the nation's three-tier federal structure in 1976. Although Lagos State is the smallest state in Nigeria, with an area of 356 , 861 hectares of which 75,755 hectares is wetlands, yet it has the highest population, which is over five percent of the national estimates. The state has a population of 17 million out of a national estimates of 150 million (Lagos State; 206).

The United Nation (UN) estimated that the growth rate of Lagos state will be third largest mega city of the world by the year 2015 after Tokyo in Japan, Bombay in India. Of this population, metropolitan Lagos with an area covering $37 \%$ of the land area of Lagos State is home to over state population. The rate of population growth is about 600,000 per annum with a population density of about 4,193 person in the built-up area of metropolitan Lagos, the average density is over 20,000 persons per square $\mathrm{km}$. Lagos population is growing faster than New York and Los Angeles cities with grave implication for urban sustainability (Mabogunje, 2001).

The reasons why Lagos State Government created another newly thirty-seven local governments was due to 1984, Dasuki led panel of local government reform, although the military in 1985 set up a specific criteria for creation of local government. These criteria are:

i. Minimum population of 100,000 to 150,000 ;

ii. Minimum tax-paying population of 20,000;

iii. Traditional association and wishes the community seek in the area;

iv. Geographical contiguity;

v. Financial viability; and

vi. Administrative Convenience (Gboyega, 1987).

The Lagos case has been raised by Southern elites who have since 1990s agitated against so called northern domination. It is alleged that successive "northern" military rulers favored the North in the creation of States and local government (Ukiwo, 2007). The Southern elites therefore, insisted that central to the resolution of National Question is restructuring of the "unbalance" federation. The local governments are unevenly distributed across geo-political zones. The North West zone has a quarter (24\%) of the LGAs in the country while other five zones have between 12 and 18\%. (Adeyemi, 2012).

\section{Conclusion}

There is no doubt that development areas are in the best position to play a major role in the grassroots development in Nigeria. As the nearest government to the people, much is expected of it hence the need for an effective and result-oriented administration. This study vividly shows that although Section 7(1) of the Constitution states that the "system of local government by democratically elected local government council is guaranteed", it empowers a state's House of Assembly to make laws to ensure their existence, structure, finances and functions, thus "detracting from the desired constitutionally guaranteed autonomy." It is in the area of 
finance that the subordination of LGCs to the centre and federating states is more encompassing. While the law is very clear as to which tier has the power to create new LGAs, it is equally clear that the president (executive rascality) has no powers to seize statutory grants from the Federal Account simply because the newly created LGAs are yet to become operative pursuant to section 8(5) of the constitution.

The study have presented an adroit evaluation of role of development area as a catalyst for rural and community development. However, there are divergent opinions on need for the creation of development areas in Nigeria. Some were of the view that such initiative may at the long run stifle development since the fund meant for a particular local government will be shared to the respective development areas while others believed that the creation of development area is a way of bringing development closer to the grassroots level. Being that as is may, local government in Nigeria since independent have been complaining of zero allocation whereas, the State government have consistently refused to remit local government funds as at when due. Therefore, the idea of creating development area could be lofty but funding of development programmes has been very difficult if not impossible.

In most parts of the world, local governments serve as catalyst for rural/national development but in Nigeria, local governments are seen as appendage with no discretionary power. One of the common problems is confusion of identity. On the creation of new local governments by state governments, the implications are far reaching. At present local governments are finding it difficult to operate as a third tier of government because of the limited funding. This was further exacerbated by the creation of new local governments. The sheer high overhead cost of running 774 local governments has almost crippled the capacity of local governments to deliver social services to the people. The situation has worsened since the creation of new local governments by some states in Nigeria. The basic concern is the economic, political and legal implications of this by increasing the number of local governments in the state, one or two things are bound to happen- the overhead cost of administration of local governments and quest for their sustainability. The local governments are not promoting development, politically or economically. The creation of new local will be uncreative means of dealing with aspects of the national question in Nigeria.

The cost of government has been huge and a burden on the economy; it is not realistic to create new local government. On the issue of state local government account, there are allegations that states are tempering with the statutory allocations to local governments from the federation account thereby leaving them with little or nothing to settle recurrent. The political elites do mobilize groups on ethno regional interests to campaign for local government creation and development. These elites often argue that local government creation fosters growth and development, bring government nearer to the people, prevent racour and ensure popular participation as the critical bases for creating local governments. The political class argues for local government creation to foster access to statist institutions and structures and engender political inclusion of marginalized subnationalities. These arguments of the political elite are flawed in the light of the historicity of local government creation and its politics in Nigeria. The political classes are the greater beneficiaries; the replications of local government.

\section{Recommendations}

The following recommendations are considered pertinent in attempts determining the desirability or otherwise of establishing development areas by state governments in Nigeria:

1. There is need for constitutional amendment in order to legalize the setting up development areas at the state level in efforts to bring government closer to the people at the grassroots level in Nigeria.

2. There is need for improvement in the sources of internally generated revenue at the State, local government and development area levels in Nigeria in order to raise more revenue for the running of development areas in Nigeria. Over dependence on intergovernmental fiscal transfers from the Federation account may not encourage rural and community development.

3. There is need for more political education at the development area levels on the benefits of participating in political activities. Specifically, the rural dwellers should be properly educated on the need to vote for those who will represent their interests in government. This will go a long way towards the enhancement of rural and community development.

4. The major purpose of creating local government is to bring development to the grassroots. In order to perform adequately, there is need for local councils to have a strong economic base. In this connection, it is suggested that statutory allocations to local council be reviewed upward. In addition to that, councils' shares of federation account to be released to them directly to avoid lateness in the payment of salaries and arbitrary deductions by the State government.

5. The creation of development areas to satisfy parochial and patrimonial needs will not move the country forward. States creation is not, in the least, a solution to the myriad problems the country is facing. Previous exercises have never been done from the perspective of bringing government and development closer to the people. Rather, it has been to score some political goals and satisfy particular 
interests. Again, experience has shown that local government creation in Nigeria over the years has not brought about the desired or expected effects. The creation of local governments is therefore not a solution to the problems of development and democracy in Nigeria. Rather, the exercise will create opportunities and developments which will liberate new forces and throw up more challenges. The continued agitations for the creation of more local

6. The continued agitations for the creation of more local governments are simply an easiest way of having access to power and wealth. To actually get the government and development to the people, there is need to reposition the Local Government, which is the closest tier of government to the grassroots. For now, the Local Governments and development areas are operating under the strangulating control of State Governors. They are centers of corruption and mediocrity. The powers and functions of the Local Government system should be enshrined in the Constitution and their finances ensured.

\section{REFERENCES}

Adelakun, J.B. (2013). Rural-Urban Development Dichotomy: A Debate. Being a text Presented on the FlaggOff of Osun Rural Awareness Campaign organized by the State of Osun Local Service Commission. February, 5-8

Ademolekun, L. (1983). Public Administration: A Nigeria and Comparative Perspective. New York: Longman Inc.

Adeyemo, D.O (2005). Local Government Autonomy in Nigeria: A Historical Perspective. Journal of Social Sciences, 10(2): 77-87.

Afegbua, S. I. (2011). Developing Leaders-hip potentials at the grassroot level in Nigeria, Contemporary issues in Local government Administration in Nigeria, edited in Olojede I., Fajonyomi B.', and Fatile J. Lagos: Rakson Nigeria Limited

Adeyemi, O.O. (2012). The Nigerian State and Politics of State and Local Governments Creation: A Critical Appraisal .International Journal of Education Administration and Policy Studies. 4(4): 96-107

Aghayere V.O (1997). Dominant Issues in the Nigerian Local Government System: A Contemporary focus. Lagos: Imprint Services, pp. 5-6, 195.

Aghayere VO 1997. Dominant Issues in the Nigerian Local Government System: A Contemporary focus. Lagos: Imprint Services, pp. 5-6, 195.

Agbakoba R, Ogbonna M (2004). Local Government Administration and Development in Nigeria. Lagos: The Human Rights Law Services, pp. 6-7.

Agboola, T.O. (2009). Advanced Public Administration.A Seminar paper Presented to the Department of Public Administration, OAU, Ile-Ife, Nigeria.

Almond, G. \& Powell, B. (1966). Comparative politics: A developmental approach. Boston: Little Brown.

Anifowose, R. and Enemuo, F. (1999). Elements of Politics. Lagos: Sam Iroanu Publications.

Appadorai, A. (1975). The substance of Politics. New Delhi, Oxford University Press.

Apata, Z.O and Yemi, A. (2011).Creation of New Local Government in Kogi State: Problems and Prospects West Yagha and Ijumu Examples. Lokoja. Crestill publishers ltd

Asaju, .K. (2010). Local Government Autonomy in Nigeria: politics and challenges of the 1999 Constitution. International Journal of Advanced Legal Studies and Governance, Vol. 1 No.1.

Cammack, P. (1998). Capitalism and democracy in the third world. London:

Easton, D. (1953), The Political System. New York: Alfred Knopf.

Danjuma, A. and Kwanga, Z.Y. (2012).Developing Alternatives Sources of Funding Local Governments during the Period of Global Economic Recession. IOSR Journal of Business and Management.2(3): 36-40

Egwu, S. (2007).The Context and Lessons of the 2003 Elections in Nigeria. In Issac Albert,

Gboyega, A. (1987). Political Values and Local Government in Nigeria. Lagos: Malthouse Press Ltd. Joseph, R. (1999). Democracy and Prebendal Politics in Nigeria: The Rise and Fall of the Second Republic. Ibadan: Spectrum Books.

Gboyega A As Cited by VO Aghayere (1997). Dominant Issues in the Nigerian Local Government System: A Contemporary focus. Lagos: Imprint Services

Lawal, S. (2000). Local Government Administration in Nigeria: A Practical Approach in Ajayi K. (ed) Theory and Practice of Local Government, Ado Ekiti, UNAD.

Lele, U. (1975) The design of rural development: Lessons from Africa. Baltimore: the John Hopkins University Press.

Merton, R. (1957). Social Theory and Social Structure: Revised and Enlarged. London: The Free Press of Glencoe.

Mabogunje, A. (1980) The Development Process: A Spatial Perspective. London: Hutchinson and Co. Publishers Ltd. 
Oyediran, O. (1988). Essays on Local Government and Administration in Nigeria, Lagos: Project Publication Ltd, p.2.

Oladoyin, A.M. (2012). Readings in Local Government Administration.Lecture Note for M.Sc. Public Administration Students, OAU, Ile-Ife.

Obasanjo, O. (2003). Address presented at the Inauguration of the Technical Committee on the Review of the Structure of Local Government Councils in Abuja, June 25. http://www.nigeriafirst.org/speeches.html

Okoli, D.C (2001) Nigerian Government and Politics; The Changing Faces, Enugu, John Jacobs Classic Publishers Ltd. Federal Republic of Nigeria (1999)

Ukiwo, U. (2007). Creation of Local Government Areas and Ethnic Conflicts in Nigeria: A Case of Warri Delta State. www.linkinghub.elsevier.com.

Vande, P.T. (2012). Ethnicity and the Politics of State Creation in Nigeria.European Scientific Journal. 8(16)

Yagboyaju, D.A. (2008). Reciprocal Exchanges: Leadership and Followership in Nigeria's Democratization. Paper presented at a Workshop on Good Governance and Democracy in Nigeria. University of Lagos, Nigeria, November 25-26.

Yagboyaju, D.A. (2011). Nigeria's Fourth Republic and the Challenge of a Faltering Democratization. African Studies Quarterly. 12(3):93-106

Constitution of the Federal Republic of Nigeria. Lagos: Federal Government Press.

National Guidelines for Reform of Local Government (1976) Kaduna: Government Printers. 